\title{
PROVIDENCIALISMO, DECISIONISMO Y PESIMISMO ANTROPOLÓGICO. INFLUENCIA DE JOSEPH DE MAISTRE EN LA TEOLOGÍA POLÍTICA DE DONOSO CORTÉS
}

\author{
POR \\ ANTONIO Fornés MuRCiANO \\ Doctorando de la Facultad de Filosofía de la Universidad Ramón Llull
}

\begin{abstract}
RESUMEN
Juan Donoso Cortés es uno de los pensadores políticos más importantes del siglo XIX español. Con seguridad, el autor que ejerció una mayor influencia en la obra del diplomático pacense fue el tradicionalista Joseph de Maistre. Esta presencia aparece con mayor claridad en los conceptos claves de su teoría política, así el pesimismo antropológico, el providencialismo o el decisionismo. Con todo, aunque en ocasiones el marqués de Valdegamas se acerca a las tesis demaistrianas rozando la literalidad, como en la cuestión de la «teoría de la guerra», resulta injusto considerar a Donoso un mero alumno o seguidor de las tesis del saboyano. Así junto a los puntos de coincidencia entre el conde de Maistre y Juan Donoso Cortés, existen cuestiones donde el autor del Discurso sobre la dictadura difiere de las tesis de de Maistre y donde su pensamiento adquiere profundidad y personalidad propias.
\end{abstract}

Palabras ClaVe: Juan Donoso Cortés, Joseph de Maistre, pesimismo antropológico, providencialismo, decisionismo, teología política, ultramontanismo.

\section{PROVIDENTIALISM, DECISIONISM, AND ANTHROPOLOGICAL PESSIMISM. THE JOSEPH DE MAISTRE'S INFLUENCE ON THE DONOSO CORTES'S POLITICAL THEOLOGY}

\begin{abstract}
Juan Donoso Cortes is one of the most important political thinkers of the Spanish 19th century. There is no doubt that the traditionalist Joseph de Maistre
\end{abstract}


was the author who exerted a major influence on the Donoso's work. This presence can be seen clearly in the key concepts of his political theory, such as anthropological pessimism, providentialism or decisionism. Even though the Marquis of Valdegamas comes close to the demaistrianas thesis by bordering on literality, as when he speaks of «war theory», considering Donoso a mere pupil or follower of the thesis made by the Savoyard would be unfair. Although there are coincidental points between the Count de Maistre and Juan Donoso Cortes, there are also matters in which the author of Discourse on Dictatorship differs from the demaistrianas thesis acquiring then his thought its own depth and personality.

KEY WORDS: Juan Donoso Cortés, Joseph de Maistre, anthropological pessimism, providentialism, decisionism, political theology, ultramontanism.

Recibido/Received 06-02-2010

Aceptado/Accepted 30-12-2010

«Pero la sorpresa del director del seminario no tuvo límites cuando al preguntar a Julien sobre la autoridad del Papa, y ateniéndose a las máximas de la antigua iglesia galicana, el joven le recitó todo el libro del señor de Maistre». ${ }^{1}$

\section{UNA CUESTIÓN INICIAL: EL CONCEPTO DE TEOLOGÍA POLÍTICA}

Afirma con razón Johan Baptist Metz que el concepto «teología política» es polisémico, sujeto a malos entendidos y poseedor de una amplia carga histórica. ${ }^{2}$ Por eso es necesario explicitar la línea analítica de este artículo, presente en su título. Se caracteriza en él la producción ideológica de Donoso Cortés, por lo que resulta importante, en primer lugar, describir el concepto de teología política que utilizaremos a lo largo del texto. Al hacerlo nos referiremos a la definición, ya clásica, elaborada por el jurista y pensador alemán Carl Schmitt quien afirmó que era imposible que desde la inmanencia pudiese legitimarse un orden político. ${ }^{3}$

\footnotetext{
${ }^{1}$ STENDHAL, Rojo y Negro, Barcelona, Editorial Bruguera 1976, p. 155.

2 Johann Baptist Metz, Dios y tiempo. Nueva teología política. Madrid, Editorial Trotta 2002, p. 13.

${ }^{3}$ «Schmitt se aferra al postulado del orden político representativo, que refiere su legitimidad al hecho de proceder del gobierno de Dios, que él trae a fenómeno. Sólo la verdad revelada como voluntad de Dios logra fundamentar una autoridad que eleve la pretensión de ser obedecida» Wolf-Daniel HARTWich, Aleida y Jan Assmann, «Epílogo», en Jacob TAubes, La teología política de Pablo. Madrid, Editorial Trotta, 2007, 150 .
}

Hispania Sacra, LXIII

127, enero-junio 2011, 235-260, ISSN: 0018-215-X 
La tesis de Schmitt es que la modernidad no ha podido sustraerse a esta necesidad de fundamentar el orden político en lo absoluto. Simplemente ha secularizado los conceptos teológicos que hasta la Ilustración sostenían el armazón político de la cristiandad. ${ }^{4}$

Donoso, siguiendo a Joseph de Maistre, se opone a la eliminación de lo trascendente en lo político y a la sustitución del concepto histórico de autoridad descendente y de legitimación religiosa del poder por el de soberanía popular y democracia. Como el saboyano, afirma la inevitable e innegociable unidad objetiva de lo teológico y lo político. Se niega a admitir que la religión católica quede restringida al ámbito de lo privado, de la pura opción personal.

La base de este posicionamiento descubre una total desconfianza en el ser humano y en su capacidad. El hombre, debilitado por el pecado original, es incapaz, por la mera fuerza de su razón, de hallar la verdad y fundamentar un edificio político. Necesita de la Revelación y, por tanto, de la teología como tutora e iluminadora de todo poder. ${ }^{5}$ Resultando así que Juan Donoso Cortés, como el conde de Maistre, encaja en el sentido de la teología política que pretende Schmitt, quien se apoya en ellos. ${ }^{6}$

Puede establecerse una distinción entre teología política y política teológica que serviría para hacer más inteligible la polémica entre Schmitt y Erik Peterson. ${ }^{7}$ La teología política es una teología, en la cual los símbolos teológicos funda-

\footnotetext{
4 «Todos los conceptos significativos de la moderna teoría del Estado son conceptos teológicos secularizados. Y no lo son debido a su evolución histórica, por haberse transferido de la teología a la teoría del Estado -al convertirse el Dios todopoderoso, por ejemplo, en el legislador omnipotente-, sino también con respecto a su estructura sistemática, cuyo conocimiento es preciso para el análisis sociológico de dichos conceptos». Carl Schmitт, Teología política I. Cuatro capítulos sobre la teoría de la soberanía, en Héctor ORESTES (prólogo y selección de textos), Carl Schmitt, teólogo de la política. México, Fondo de Cultura Económica, 2001, p. 43.

5 «El que usa el concepto de teología política, parte de la no autarquía del hombre, de la insuficiencia de sus competencias innatas y adquiridas, de la imposibilidad de que funde inmanente y racionalmente su modo de vida». Wolf-Daniel HARTWICH, Aleida y Jan ASSMANN, «Epílogo»...51.

${ }^{6}$ «Desde 1848 la teoría jurídica del Estado se tornó positiva y por lo común utilizaba esta palabra para ocultar su confusión, o bien basaba todo el poder en el pouvoir constituant del pueblo, recurriendo a las circunscripciones más diversas: la idea monárquica de legitimidad fue sustituida por la democrática. Por consiguiente, revistió una importancia inmensa que uno de los más grandes representantes del pensamiento decisionista, un filósofo católico del Estado, consciente -con extraordinario radicalismodel núcleo metafísico de toda política, Donoso Cortés, comprendiera, al enfrentar la revolución de 1848, que la época del realismo había llegado a su fin. El realismo había dejado de existir porque ya no había reyes. Por lo tanto, tampoco existía la legitimidad en el sentido tradicional. Por ende sólo le quedaba una conclusión posible: la dictadura. Se trata del mismo resultado al que llegó Hobbes a partir de la misma consecuencia del pensamiento decisionista, si bien mezclada con cierto relativismo matemático: Autoritas, non veritas facit legem». Carl Sснмітт, Teología política I. Cuatro capítulos sobre la teoría de la soberanía....52.

${ }^{7}$ Carles Llinàs i Puente, «Erik Peterson: Política escatològica», Revista Catalana de Teologia XXVIII/2 (2003) 407-455
} 
mentales se someten y subordinan a conceptos políticos. Esta sería también la postura de Donoso, y en la que se encontraría también Carl Schmitt.

Al contrario, en una política teológica, los conceptos políticos se subordinan a los teológicos. Es lo que defiende Peterson. Esquematizada, la propuesta de Peterson tendría una voluntad ascendente, mientras que la de Schmitt sería claramente descendente. En el trasfondo de esta sutileza ideológica ${ }^{8}$ aparece la voluntad de Erik Peterson de desmarcarse de la propuesta política de Schmitt, para poder, sin obviar la densidad política del mensaje cristiano, negar a éste la posibilidad de avalar un régimen político. ${ }^{9}$

\section{DONOSO CORTÉS Y DE MAISTRE}

«La reputación de Donoso Cortés fue grande y universal, pero mucho más efímera, ligada en parte a las circunstancias del momento, y debida más bien a la elocuencia deslumbradora del autor que a la novedad de su doctrina, cuyas ideas capitales pueden encontrarse en De Maistre, en Bonald y en los escritos de la primera época de Lamennais. Balmes parece un pobre escritor comparado con el regio estilo de Donoso, pero ha envejecido mucho menos que él, aun en la parte política. Sus obras enseñan y persuaden, las de Donoso recrean y a veces asombran, pero nada edifican, y a él se debieron principalmente los rumbos peligrosos que siguió el tradicionalismo español durante mucho tiempo». ${ }^{10}$

Menéndez Pelayo, siempre reticente ante la figura de Donoso Cortés, sirve para encuadrar la innegable influencia de Joseph de Maistre en su pensamiento. El texto evidencia además, cómo la historiografía coetánea consideró a Donoso, junto a Jaime Balmes, el máximo exponente del pensamiento político español del XIX. Uno y otro presentan asimismo una posición ideológica común, conservadora, con los matices que obviamente los separan.

Begoña Urigüen, en su estudio sobre los orígenes de la derecha española, afirma que es de este dualismo doctrinal del que beberá el conservadurismo español a

${ }^{8}$ Sutileza que en cierto sentido resulta un puro constructo racional, como admite el propio Llinàs, pues en la práctica, el discurso político al respecto de esta cuestión acaba siempre participando de las dos ideas, ibidem 407.

${ }^{9} \mathrm{La}$ tesis final reviste un tenor teológico. Peterson no baja a la arena de la teoría política. Se mantiene en el campo teológico y argumenta desde él. En su opinión, el monoteísmo cristiano comporta consecuencias políticas, pero éstas no son articulables en la forma de una teología política, como ocurre en el paganismo y en el judaísmo.

A primera vista se diría que lo que Peterson rechaza es la instrumentación del evangelio para legitimar una situación política. Es decir, Peterson alza su voz en contra de la legitimación teológica del orden político, en contra de la justificación teológica de la publicidad política desde la teológica». Gabino URíBARRI, «Prólogo», en Erik PETERSOn, El monoteísmo como problema político, Madrid, Editorial Trotta 1999, 37-38.

10 Marcelino MenÉndez Pelayo, «Dos palabras sobre el centenario de Balmes», Ensayos de crítica filosófica, Madrid, Librería General de Victoriano Suárez 1918, 368.

Hispania Sacra, LXIII

127, enero-junio 2011, 235-260, ISSN: 0018-215-X 
lo largo de todo el siglo XIX. ${ }^{11}$ Genovés no duda en calificarlos como «las figuras más destacadas del movimiento reaccionario doctrinal del pasado siglo español». ${ }^{12}$ Olivar Bertrand, en su estudio sobre Antonio Aparisi, los entronca de nuevo en la génesis del pensamiento ultraconservador del XIX. ${ }^{13}$ Este binomio lo sostendrá también Alejandro Pidal y Mon, en el siglo XIX, y, más recientemente, José Larraz, pensador y activista católico, y Santiago Galindo Herrero, entre otros. ${ }^{14}$

La historiografía europea contemporánea ${ }^{15}$ advirtió la influencia/dependencia entre de Maistre y Donoso. Barbey d'Aurevilly, deslumbrado por el tradicionalismo de de Maistre, reconoce este ascendiente, y lo sitúa en una relación maestro y alumno: «Donoso Cortés a bien parfois l'aperçu de Joseph de Maistre, mais cet aperçu n'arrive pas chez lui comme chez de Maistre». ${ }^{16}$

Parece pues evidente y ampliamente defendida a lo largo del tiempo, la influencia de Joseph de Maistre. El objetivo de este trabajo es describirla y caracterizarla. Con todo, y junto a los amplios puntos de encuentro entre ambos autores, mostraremos también las diferencias. Así para una parte importante de la historiografía, Donoso suele ser considerado apenas un seguidor o imitador español de las teorías del tradicionalismo francés y especialmente de Joseph de Maistre. Sin embargo, esta posición no hace justicia a la obra de Donoso, más aguda y compleja de lo que el reduccionismo de ciertos planteamientos simplificadores parece querer indicar. Así lo reconoció Carl Schmitt, en su ensayo sobre Donoso. ${ }^{17}$

11 «...»hacía ya muchos años que dos grandes pensadores, Donoso Cortés y Balmes, habían creado una escuela política que, arrancando del catolicismo, resolvía por el catolicismo todos los problemas políticos». Begoña URIGÜEN, Orígenes y evolución de la derecha española: el Neocatolicismo, Madrid, Centro de Estudios Históricos CSIC 1986, p.63.

12 Vicente Genovés Genovés, (selección y prólogo), Aparisi y Guijarro. Antología, Madrid, Ediciones Fe, 1943, p. 6.

13 «...paladín de la continuidad histórica española es Aparisi Guijarro, que con Balmes y Donoso Cortés se enlaza para dar corporeidad al tradicionalismo de la primera a la segunda mitad del siglo XIX», Rafael Olivar Bertrand, Aparisi Guijarro, Madrid, Instituto de Estudios Políticos, 1962, IX.

14 Alejandro Pidal y Mon, Balmes y Donoso Cortés. Orígenes y causas del ultramontanismo. Su historia y sus transformaciones. Relaciones del Estado con la Iglesia española y con la Santa Sede, Madrid, Ateneo Científico, Literario y Artístico de Madrid. La España del siglo XIX. Colección de conferencias históricas, curso 1886-1887. José LARRAZ, Balmes y Donoso Cortés, Madrid, Rialp 1965. Santiago Galindo HerRero, «Donoso Cortés en su paralelo con Balmes y Pastor Díaz», Revista de Estudios Políticos, 69 (1953) 111-140.

15 Donoso es el pensador político español del XIX, con mayor prestigio e influencia internacional. Así sus discursos fueron frecuentemente publicados por periódicos de inclinación católica en Francia, Bélgica, Italia... Elogiado incluso por el cínico Metternich, su obra fue comentada por Schelling y Ranke y sus escritos llegaron incluso a manos de Luis Napoleón, Federico Guillermo IV, o el zar Nicolás... Federico SuÁREZ, Introducción a Donoso Cortés, Madrid, Rialp 1964, 168).

16 Jules Barbey D'Aurevilly, XIX Siècle. Les Oeuvres et les Hommes. Première partie: Philosophes et écrivains religieux, París, Amyot 1869, 34.

17 «En su suprema culminación existencial, que alcanzó bajo la impresión de los terrores de 1848 , fue también infinitamente más que un orador influido por de Maistre, Tocqueville o Gioberti», Carl Schmit, Interpretación europea de Donoso Cortés, Madrid, Rialp 1952, 59. 
Más allá de influencias, Donoso Cortés suscita interés por sus aportaciones originales, discutibles o no, que merecen su estudio.

\section{LA EVOLUCIÓN DEL PENSAMIENTO DE DONOSO}

La «presunta» evolución de su pensamiento interesa, evidentemente, por la posibilidad de interrelacionar «la radicalización política» del autor con su mayor profundización en las teorías de de Maistre. Es habitual en los manuales afirmar un primer momento de «liberalismo doctrinario» en Donoso. ${ }^{18}$ Desde él, se movería hasta culminar en su doctrina reaccionaria, impulsada por los acontecimientos de 1847-48, muerte de su hermano, crisis personal y estallido revolucionario del 48 . En ese momento se produce la influencia decisiva del tradicionalismo francés, pero esta compartimentación debe matizarse.

La lectura de Donoso permite darse cuenta de que su ideario político, basado en el orden, la tradición, la autoridad y la negación de toda intervención directa del pueblo en los asuntos públicos, se mantiene constante a lo largo de toda su vida. Es posible encontrar en muchos textos de su época doctrinaria-liberal afirmaciones con estas ideas. ${ }^{19}$

Desde sus inicios intelectuales, Donoso ve con prevención al parlamentarismo democrático, que juzga mera discusión vacua y alejamiento de la única verdad que es la Revelación. Por eso se sitúa a favor de cualquier régimen que defienda a la religión como única vía para desarrollar un sistema político justo y realmente fundamentado, incluida la dictadura. ${ }^{20}$ Así lo ha puesto de relieve Antonio Rivera. ${ }^{21}$

\footnotetext{
18 Salvador Giner, Historia del pensamiento social, Barcelona, Ariel 1967 (sexta edición), 408410 .

19 «Creyendo de buena fe que el pueblo de Roma había sido soberano, proclamaron la soberanía del pueblo como un principio, siendo sólo una máquina de guerra. Creyendo de buena fe que las Repúblicas antiguas habían sido gobiernos democráticos, quisieron depositar el Poder en manos de la democracia, que no le ha tenido nunca de una manera estable, porque el principio democrático es el principio disolvente de todos los Gobiernos», Juan Donoso, Obras Completas I, Madrid, BAC 1946, 648.

20 «El pueblo no se queja, no puede quejarse de una dictadura que le salva; pero, obedeciendo irresistiblemente a un poderoso instinto de justicia, quisiera examinar los títulos del dictador que se la impone; quisiera convencerse de la legitimidad de sumisión por la legitimidad de su origen», Ibidem 633.

${ }^{21}$ «En el Donoso Cortés de su etapa moderada o doctrinaria, el de las Lecciones de derecho político de 1836-37, ya se encuentra esta concepción de libertad católica ajena al sentido liberal e ilustrado de la Constitución de Cádiz. Antes de la denominada «conversión» reaccionaria, aunque realmente no sea tal porque mucho antes de la muerte del hermano y de la revolución del 48 su pensamiento ya está madurado, sus convicciones católicas resultan innegables», Antonio RIVERA GARCÍA, Reacción y Revolución en la España Liberal, Madrid, Editorial Biblioteca Nueva 2006, 168.
}

Hispania Sacra, LXIII

127, enero-junio 2011, 235-260, ISSN: 0018-215-X 
Varía solo su inicial ingenuidad filosófico-política, pues, se muestra al principio confiado en que la racionalidad, que llama dictadura de la inteligencia, ha de imponerse sobre el régimen liberal. ${ }^{22}$

Cuando se fue desengañando con la política, abandonó el racionalismo como fundamento, convencido de que ninguna teoría inmanentista era capaz de dar razón última de ningún sistema político. Buscó entonces en la trascendencia, en Dios, esa base, trasformando de alguna manera su filosofía política en teología política.

Donoso, por tanto, aunque cambia los cimientos de su construcción, mantiene inalterable el edificio a lo largo de su vida. Cambia eso sí, el tono de su oratoria, el estado de ánimo con que se expresa, que, con los años, es más desabrido y desesperado, acentuándose el tono escatológico de sus discursos.

Este rasgo es otra influencia de de Maistre. Donoso conoció la obra de éste al inicio de su carrera política. Así, en los argumentos de una de sus primeras obras, Memoria sobre la Monarquía (1832), hay ideas tomadas de aquel, utilizadas para defender la legitimidad de la Pragmática Sanción. ${ }^{23}$ En cualquier caso, a partir de su estancia/retiro en Francia entre 1840 y 1843, sus escritos muestran con más claridad la influencia del tradicionalismo en general y de Joseph de Maistre en particular. Esto resulta indudable ya en sus Cartas desde París (1842), donde, prácticamente, parafraseará la teoría de la guerra esbozada en la séptima velada de Les soirées de Saint-Pétersbourg.

SAN AGUSTÍN COMO INFLUENCIA COMÚN Y «LA REVOLUCIÓN» COMO MOTOR DE PENSAMIENTO

Donoso y de Maistre comparten el origen teórico y práctico de su pensamiento. Resultan «almas gemelas». Muestran ambos la influencia de fondo de San Agustín, especialmente de su perfil antropológicamente más pesimista, el de su agria polémica contra Pelagio. ${ }^{24}$ En los dos, el pecado original está conti-

\footnotetext{
22 «Queda demostrado por la razón que el dominio del mundo pertenece a la inteligencia, y por consiguiente, que el poder legítimo es siempre uno e idéntico en su origen: queda demostrado por la Historia que el ejercicio del poder está reservado siempre a los hombres, a las clases o a los pueblos a quienes la inteligencia concede la dominación», Obras Completas I... 193.

${ }_{23}^{3}$ Jules ChaIX-Ruy, Donoso Cortés. Theólogien de l'Histoire et prophète, París, Beauchesne 1956, 36.

${ }^{24}$ San Agustín se muestra a lo largo de toda su obra pesimista al respecto de las posibilidades del hombre para luchar contra el pecado. Para él, la finitud del hombre y su degeneración a causa del pecado original le imposibilitan para, sin la ayuda de la gracia divina, ejercer el bien y amar verdaderamente a Dios. Esta posición se radicaliza al luchar contra la «optimista» herejía de Pelagio, quien afirma que el hombre puede salvarse por sus propias fuerzas. El texto del propio San Agustín define bien ambas posiciones: «Dice Pelagio: He dicho en efecto, que el hombre puede vivir sin pecado y observar los mandamientos divinos, si quiere, por cuanto Dios le ha concedido esa posibilidad. (...) No es posible
} 
nuamente presente, lastrando la historia humana y debilitando al hombre no sólo en el plano moral sino también epistemológico. El escepticismo de base y la afirmación de la incapacidad del hombre para conocer por sí mismo la verdad, está siempre presente en el saboyano.

«La raison humaine est manifestement convaincue d'impuissance pour conduire les hommes; car peu sont en état de bien raisonner sur tout; en sorte qu'en général il est bon, quoiqu'on en dise, de commencer par l'autorité». 25

«(...) qu'il n'y a point d'homme innocent dans ce monde; que tout mal est une peine, et que le juge qui nous y condamne est infiniment juste et bon». ${ }^{26}$

Superada su fase racionalista, e iluminado por de Maistre, aparece también con claridad en Donoso:

«La civilización católica enseña que la naturaleza del hombre está enferma y caída; caída y enferma de una manera radical en su esencia y en todos los elementos que la constituyen. Estando enfermo el entendimiento humano, no puede inventar la verdad ni descubrirla, sino verla cuando se la ponen por delante; estando enferma la voluntad, no puede querer el bien ni obrarle sino ayudada, y no lo será sino estando sujeta y reprimida. Siendo esto así, es cosa clara que la libertad de discusión conduce necesariamente al mal». ${ }^{27}$

En esta postura común, ambos autores miran al mismo tiempo en dos direcciones. Se inspiran y se apoyan en una interpretación nominalista extrema, cercana al protestantismo, sin que ellos sean consciente del todo, pues su postura pretende ser ultraortodoxa. ${ }^{28}$ De San Agustín toman la convicción de que el

saber lo que por estas palabras entiende Pelagio con el nombre de gracia; y los jueces, como católicos, entendieron que esta gracia o era otra cosa que la que tanto nos predica la doctrina apostólica. (...) Para alcanzar esta gracia pedimos a Dios que no nos deje caer en la tentación. Esta gracia no es la naturaleza, sino ayuda de la frágl y viciada naturaleza, sino aquella gracia de la que dice el Apóstol: No repudio como nula la gracia de Dios; porque, si por la ley se alcanzase la justicia, entonces Cristo hubiera muerto en vano; y por eso no es letra que mata, sino espíritu que vivifica. Porque el conocimiento de la ley sin la gracia del espíritu obra en el hombre toda la concupiscencia». (San Agustín OC IX, 711-713).

${ }^{25}$ Joseph de MAISTRE, Oeuvres complètes, Lyon, Libraire générale catholique el classique 1891, vol IV, p.108.

${ }^{26}$ Ibidem vol IV, p. 190.

27 Juan Donoso CoRTÉs, Obras... vol II, p. 325.

${ }^{28}$ También Carl Schmitt advierte no sólo el pesimismo antropológico exacerbado de Donoso, evidente para quien lea su obra, sino la cercanía de sus conclusiones a las del luteranismo, de quien se considera enemigo acérrimo y a quien culpa en última instancia del triunfo de la Revolución: «(...) el cristiano católico se basó en el dogma del pecado original. Ciertamente lo radicalizó en términos polémicos hasta convertirlo en una teoría del carácter pecaminoso y abyecto absoluto de la naturaleza humana. Cabe subrayar que el dogma tridentino del pecado original no es radical en sí. A diferencia de la interpretación luterana, no habla de infamia sino sólo de un deformación, perturbación, vulneración, y deja por completo incólume la posibilidad de la bondad natural». (Carl Sснмiтt, Teología política I. Cuatro capítulos sobre la teoría de la soberanía, opus cit., p.52.)

Hispania Sacra, LXIII

127, enero-junio 2011, 235-260, ISSN: 0018-215-X 
hombre no puede conocer la verdad y ejercer el bien de forma puramente racional sin la ayuda de la gracia. Pretenden además atacar frontalmente al ideal ilustrado de autonomía de la razón y la necesidad, por tanto, de liberarse del estrecho y dañino corsé de la religión. En estas ideas uno y otro ven la razón última de los movimientos revolucionarios.

«La razón humana no puede ver la verdad si no se la muestra una autoridad infalible y enseñante: la voluntad humana no puede querer el bien ni obrarle si no está reprimida por el temor de Dios. Cuando la voluntad se emancipa de Dios y la razón de la Iglesia, el error y el mal reinan sin contrapeso en el mundo». ${ }^{29}$

En el origen de estas ideas está la Revolución, que es la chispa que las provoca. ${ }^{30}$ Para de Maistre y para Donoso, la Revolución supone el estallido del pecado, el triunfo del «filosofismo» frente al cristianismo, el horror del apocalipsis, y sobre todo y más importante, la Revolución es un ataque directo del mal sobre el orden divino, establecido por Dios en el mundo a través de la creación. En de Maistre no hay que añadir nada al respecto.

«Or, ce qui distingue la révolution française, et ce qui en fait un événement unique dans l'histoire, c'est qu'elle est mauvaise radicalement; aucun élément de bien n'y soulage l'œil de l'observateur: c'est le plus haut degré de corruption connu; c'est la pure impureté».31

En Donoso, si bien es cierto que sus escritos en esta línea se remontan con anterioridad al 48, es a partir de entonces cuando su oratoria alcanza mayor virulencia y también mayor profundidad.

«La Francia, señores, en mala hora, resolvió este problema en el sentido de la industria y en el sentido del orden en las calles; cada paso que daba en esta senda era un paso que

Esta circunstancia se da también en de Maistre, autor de líneas terribles contra el reformista religioso alemán y que paradójicamente habría firmado muchos de los textos políticos de Martín Lutero. Veamos uno de esos textos: «Como ningún hombre es por naturaleza cristiano o piadoso sino que todos son pecadores o malos, Dios les prohíbe a todos ellos, por medio de la ley, que pongan en práctica su maldad con obras externas, según sus malas acciones». Martín LuTERO, A la nobleza cristiana de la nacion alemana acerca de la reforma de la condición cristiana, en Martín LUTERO, Escritos políticos, Madrid, Editorial Tecnos, 1990, 29.

${ }^{29}$ Ibidem, vol II, p. 207.

${ }^{30}$ La misma opinión es sostenida, entre otros, por Edmund Schramm, quien en su monumental estudio sobre Donoso Cortés afirma: «La «cultura católica» es, en último término para Donoso, el desarrollo de un orden establecido directamente por Dios, de un orden que elude la intervención humana. La «cultura racionalista» es producto del desorden ocasionado por el pecado. Este desorden ha encontrado su expresión más pavorosa y terrible en la Revolución Francesa, que, naturalmente, también para Donoso es el punto de arranque de su pensamiento, pues al cabo la Revolución de 1848, cuyos efectos sintió directamente, sólo es un eslabón...» (Edmund Schramm, Donoso Cortés, su vida y pensamiento, Madrid, Espasa Calpe 1936, pp. 244-245).

${ }^{31}$ Joseph de Maistre, Oeuvres... vol I, p.50. 
daba lejos de su Dios, y cada paso que daba lejos de su Dios era un paso que daba hacia la boca del abismo. Dios la alcanzó cuando llegaba a su boca; Dios la alcanzó el 24 de febrero, el día de la grande liquidación, el día de los grandes anatemas. ¿Qué sucedió? Que ese pueblo, desvanecido con su poder, embriagado con su riqueza, loco con su industria, vio abismarse juntamente su industria, su poder y su riqueza en el gran diluvio republicano. Todo, señores, todo acabó allí: el gran pueblo y el gran rey, el obrero y su obra».32

\section{Filosofía DE LA HISTORIA. PROVIDENCIALISMO Y ESCATOLOGÍA}

La pesimista visión antropológica de de Maistre y de Donoso trasciende lo individual. Es una herramienta de interpretación de la sociedad. Transforman su planteamiento antropológico en filosofía/teología cambiando su concepto clave: de la gracia para el individuo a la Providencia para la sociedad:

«Las sociedades están sometidas a las mismas leyes que los individuos. También las sociedades, como la totalidad de los hombres en ellas incluidos, padecen la debilidad heredada del pecado original. Si ellas quieren realizar el bien en sus acciones y preservarse de la ruina y de la caída, tendrían que invocar y servirse de la Gracia divina, exactamente lo mismo que los individuos. Si intentan, por el contrario, realizar el bien rechazando la Gracia divina y sirviéndose únicamente de sus propias fuerzas, entonces fracasarán «naturalmente» por obra de su naturaleza debilitada. El mal obtendrá en ellas la victoria.(...) Siempre es Dios el que debe intervenir para remediar la debilidad y maldad de los hombres. La maldad se atestigua, sobre todo, en la repudiación de la Gracia. Si las sociedades obedecen de buena voluntad el mandato divino, entonces actúa él con su gracia, invisible, secreta y suavemente».33

Esta filosofía de la historia busca no sólo su fundamentación, sino su clave de interpretación en el hecho religioso. ${ }^{34}$ Es la Providencia, y no la voluntad humana la que, en último término, rige el acontecer histórico. El papel de la sociedad se reduce a la aceptación o no de la verdad revelada y a soportar las consecuencias de su decisión. La construcción teórica que de Maistre y Donoso

32 Juan DONOSO CORTÉs, Obras..., VOL II, p. 337.

${ }_{3}$ Dietmar WestemeYer, Donoso Cortés hombre de estado y teólogo, Madrid, Editora Nacional 1957, pp.186-187.

${ }^{34}$ A lo largo de todo este apartado entendemos por filosofía de la historia, siguiendo a Karl Löwith, «una interpretación sistemática de la Historia Universal, de acuerdo con un principio según el cual los acontecimientos históricos se unifican en su sucesión y se dirigen hacia un significado fundamental». (Karl Löwith, El sentido de la Historia. Implicaciones teológicas de la filosofía de la historia, Madrid, Aguilar, 1973, p. 7). Pensamos que esta definición encaja con el tipo de planteamiento en el que se mueven tanto de Maistre como Donoso, pues resulta fácil advertir que desde este punto de vista, inevitablemente, el concepto filosofía de la historia pasa a depender de la teología y de su concepto de la historia como un camino en pos de la salvación final de la humanidad. De alguna manera, la filosofía de la historia así considerada se resiste a ser considerada como una ciencia en el sentido moderno del término pues carece de «base científica» al estructurarse fundamentalmente en función de la Revelación cristiana.

Hispania Sacra, LXIII

127, enero-junio 2011, 235-260, ISSN: 0018-215-X 
elaboran se caracteriza mejor si la definimos como teología de la historia. ${ }^{35}$ Es éste un tema clave, fundamental, que informa todo su pensamiento, una cuestión que los une y separa radicalmente a un mismo tiempo.

Para los dos, Dios interviene en la historia directamente y a través de las acciones de los hombres.

«On ne saurait trop le répéter, ce ne sont point les hommes qui mènent la révolution; c'est la révolution qui emploie les hommes. On dit fort bien, quand on dit «qu'elle va toute seule». Cette phrase signifie que jamais la Divinité ne s'était montrée d'une manière si claire dans aucun événement humain. Si elle emploie les instruments les plus vils, c'est qu'elle punit pour régénérer». ${ }^{36}$

\section{El mundo está regido por la Providencia, y ante ella los hombres son impo- tentes, apenas puras marionetas:}

«Yo he admirado aquí y allí la lamentable ligereza con que se trata de las causas hondas de las revoluciones. Señores, aquí, como en otras partes, no se atribuyen las revoluciones sino a los defectos de los gobiernos. Cuando las catástrofes son universales, imprevistas, simultáneas, son siempre cosa providencial; porque, señores, no otros son los caracteres que distinguen las obras de Dios de las obras de los hombres». ${ }^{37}$

\footnotetext{
${ }^{35} \mathrm{D}$. Westemeyer, probablemente el ensayista que ha estudiado a Donoso desde una perspectiva más teológica, resume con claridad este posicionamiento, nuclear en la ideología del extremeño, del pensamiento religioso como base e inicio de todo pensamiento filosófico-político: «El desarrollo de la prueba de nuestro teólogo es el siguiente: Dios es el océano de todas las cosas. Él no sólo lleva y mantiene todas las cosas en el ser del modo como su Omnipotencia las trajo a la existencia; en Él están también, al mismo tiempo, las leyes de todo lo creado, a la manera como en Él vivían sus ideas antes de crearlas. Las cosas y sus leyes no existen separadas de Dios, sino que tiene en Él su existencia. Por eso todo hombre tropieza cuando se ocupa con las cosas y con las leyes al mismo tiempo con Dios; no puede percibir las cosas y sus leyes de otro modo que al través de Dios. «Posee la verdad política quien conoce las leyes a las que están sometidos los Gobiernos; posee la verdad social quien conoce las leyes a las que están sometidas las sociedades humanas; conoce estas leyes quien conoce a Dios; conoce a Dios quien escucha sus palabras y cree en Él. La Teología es la ciencia que tiene por objeto estos enunciados. De ahí se sigue que los enunciados sobre la sociedad y el Gobierno suponen un enunciado sobre Dios, o, lo que es lo mismo, que toda verdad política o social necesariamente se reduce a una verdad teológica». (Dietmar WestemeYer, Donoso Cortés hombre de estado..., p.151). También un autor más moderno, como Perrini, ahonda en la misma línea de análisis del pensamiento donosiano: «Il nesso teología politica culmina pero nel problema dell'origine de potere che è la grande questione di ogni sistema político. Con la venuta di Cristo sulla terra, observa Cortés, l'uomo retorna in possesso di quelle leggi che con il pecatto originale aveva smarrito. L'ordine ristabilito si irradia e trapassa dalla sfera religiosa a quella morale e da questa alla sfera della realtà politica». (Bruno PERRINI, Donoso Cortés. La concezine della storia e la sua polemica con i liberali e $i$ socialista, Milano, A. Giuffrè 1980, p. 101).

36 Joseph de Maistre, Oeuvres..., vol I, p. 7.

37 Juan Donoso CoRTÉs, Obras..., vol II, 192.
} 
Pero en la afirmación del dominio de la Providencia sobre la historia, paradójicamente, se separan. Es un caso más de enfrentamiento entre las dos grandes corrientes de Filosofía de la Historia en el pensamiento occidental: san Agustín frente a Joaquín de Fiore. Donoso toma de de Maistre la idea del providencialismo y el acento escatológico, pues ambos viven una lucha final que marca el fin de una era. El influjo de San Agustín desmarca del tradicionalista francés a Donoso, que tiene una visión más pesimista ${ }^{38}$ respecto al futuro de la humanidad, mientras de Maistre acepta el optimismo iluminista/escatológico.

Puede incluirse a Donoso en una filosofía de la historia «meta-histórica», que ha conformado la línea ortodoxa de la reflexión cristiana. Aun pudiendo remontarse a san Pablo, tomará un peso decisivo en el siglo III, con Orígenes, quien afirma que el triunfo del Reino no ocurrirá ni en el espacio ni en el tiempo, sino en las almas de los creyentes. Su exponente definitivo será San Agustín, especialmente el libro XX de la Ciudad de Dios. Sosteniendo que el Apocalipsis debe entenderse alegóricamente, pues el momento central de la historia, encarnación de Cristo, ya ha pasado. El cumplimiento escatológico del cristiano tiene lugar en la otra vida. Este pensamiento agustiniano está muy presente en Donoso. ${ }^{39}$

\footnotetext{
${ }^{38}$ De ahí que cuando se aborda el estudio de la contrarrevolución en España haya que tener cuidado con generalizaciones que no reparan en los diferentes matices que presenta cada autor, de manera que establecen conclusiones erróneas. Resulta ejemplificador al respecto el comentario de Antonio Rivera: «Pero, cuando se cree en la providencia divina el pesimismo tan sólo puede ser relativo. Los contrarrevolucionarios españoles y europeos saben que Dios consiente el pecado de la revolución con el objeto de castigar la soberbia moderna y regenerar las conciencias contaminadas por las escuelas liberales y socialistas. La divinidad permite el mal para extraer el bien de la redención, sin el cual no es posible la restauración de una Europa católica. La victoria definitiva corresponderá siempre, sin la menor duda, a las huestes de Dios» (Antonio RiverA, Reacción y Revolución en la España Liberal, opus cit., p. 27) En el caso de Donoso, la lectura de sus textos deja claro que su pesimismo es total, y que la revolución triunfará inevitablemente. Otra cuestión es que obviamente en la mentalidad del pacense es la Providencia quien permite este triunfo como una forma de castigo por el abandono por parte de Europa de la senda cristiana. La victoria del bien se dará para Donoso no en el mundo material, sino en la vida eterna, a diferencia de de Maistre quien sí se adaptaría mejor al esquema planteado por Rivera, pues su escatología posee un enfoque de optimismo inmanentista evidente.

39 «La unión entre el espíritu y sus manifestaciones políticas es concebida tan estrechamente, que las contraposiciones de liberalismo político, relativamente del socialismo y de la monarquía, son sustituidas por las de Revolución y Catolicismo, civilización filosófica y civilización católica. (...) Por eso se alza el combate de la actualidad desde el plano de las decisiones relativas, terrenalmente importantes, a la altura de las decisiones absolutas y morales. Desde un combate de partidos y campamentos terrenales para convertirse en una lucha de la Ciudad de Dios con la Ciudad del Mundo. No en vano se repite esta imagen muchas veces en Donoso. Y apenas puede dudarse de que él relaciona la lucha concreta de la actualidad con esta lucha trascendente, si es que no las identifica». (Dietmar WESTEMEYER, opus cit., pp. 205-206).
}

Hispania Sacra, LXIII

127, enero-junio 2011, 235-260, ISSN: 0018-215-X 
«Aquí se trata de una cuestión muy grave: se trata de averiguar nada menos cuál es el verdadero espíritu del catolicismo acerca de las vicisitudes de esa lucha gigantesca entre el mal y el bien, o, como San Agustín diría, entre la ciudad de Dios y la ciudad del mundo. Yo tengo para mí por cosa probada y evidente que el mal acaba por triunfar del bien acá abajo, y que el triunfo sobre el mal es una cosa reservada a Dios, si pudiera decirse así, personalmente».40

De Maistre, según Henri de Lubac, ${ }^{41}$ se sitúa por el contrario en una línea más inmanente. Esta corriente se remonta a la literatura apocalíptica judía. Tiene su referente canónico en el libro de Daniel. En época cristiana, lo serán las profecías e ideas escatológicas del Apocalipsis de Juan. Entre los Padres de la Iglesia podemos encontrar el influjo del milenarismo en Papías, Justino, y, sobre todo, en san Ireneo. Este, en el final de su Adversus Haereses, muestra una confianza milenarista en el progreso de la humanidad como algo que está en el plan de Dios. «La historia salvífica, comenzada en la creación, recapitulada en Cristo, se concluirá, después del milenio, en el Reino. ${ }^{42}$ Le siguen Lactancio, Comodiano y otros. Su máxima expresión fue la obra del monje calabrés Joaquín de Fiore.

Se parte de la presencia de la Providencia divina en la historia y de que se está ante un momento de lucha final, apocalíptico, en que las fuerzas del bien, identificadas con el cristianismo, se enfrentan en una última batalla frente al mal, encarnado en la Revolución. Con todo, la visión escatológica de Donoso y de Maistre difieren diametralmente. Para el primero es una lucha perdida: el filosofismo y la razón, autónomos de toda trascendencia, se impondrán inevitablemente. La victoria final como en La ciudad de Dios, sólo puede darse más allá del mundo material:

«Yo creo que la civilización católica contiene el bien sin mezcla de mal y que la filosofía contiene el mal sin mezcla de bien alguno. (...) ¿A cuál de estas dos civilizaciones está prometida en el tiempo la victoria? Yo respondo a esta pregunta, sin que mi pluma vacile, sin que se oprima mi corazón y sin que mi razón se turbe, que el triunfo en el tiempo será irremisiblemente de la civilización filosófica».43

Niega la posibilidad de todo progreso efectivo de la cultura humana. De ahí su visión de la tecnología como algo negativo que fundamentalmente sirve para

\footnotetext{
40 Juan Donoso CORTÉs, Obras..., vol II 326.

41 «En relación con el abad de Fiore, sostén de los papas de su tiempo, si la psicología es diferente, el pensamiento parece bastante cercano Por todas partes en la obra de este apologista del papado, desde que él se entrega a su propia inspiración «se entrevé este presentimiento, más o menos explícito, más o menos encubierto, de una evolución extraordinaria en el catolicismo: Todos los seres gimen y tienden con esfuerzo y dolor, hacia otro orden de cosas». (Henri de LuBAC, La posteridad espiritual de Joaquín de Fiore, Madrid, Encuentro Ediciones 1989, vol I, p.295).

42 Ramón Trevijano, Patrología, Madrid, BAC 1994, p. 83.

43 Juan Donoso CoRTÉs, Obras..., vol. II, pp. 325-326.
} 
controlar y oprimir a los hombres. Además de san Agustín pesaban en Donoso su experiencia de político profesional y el desencanto que ésta le produjo. En cambio, en de Maistre hay una ansia escatológica, una espera impaciente de un acontecimiento trascendental, algo así como la llegada del tercer y último milenio, en el que el bien/cristianismo triunfará definitivamente. Los dos comparten el pesimismo antropológico, pero en de Maistre, existe la confianza en que el progreso humano, paradójicamente, llegará a su momento definitivo, por una intervención de la Providencia a través de un terrible y violentísimo instrumento: ¡la Revolución!

«Contemplez le lugubre tableau; joignez-y l'attente des hommes choisis, et vous verrez si les illuminés on tort d'envisager comme plus ou moins prochaine une troisième explosion de la toute-puissante bonté en faveur du genre humain».44

«Ésta es la verdad. Todo anuncia, todo, para el hombre que tiene buena razón, buen sentido e ingenio penetrante, todo anuncia, señores, una crisis próxima y funesta; todo anuncia un cataclismo como no le han visto los hombres. (...) Hoy día, señores, en Europa todos los caminos, hasta los más opuestos, conducen a la perdición. Unos se pierden por ceder, otros se pierden por resistir. Donde la debilidad ha de ser la muerte, allí hay príncipes débiles; donde la ambición ha de causar la ruina, allí hay príncipes a mbiciosos; donde el talento mismo, señores, ha de causar perdición, allí pone Dios príncipes entendidos». 45

Encontramos un aspecto más, la necesidad de re-cristianizar Europa. Pese al talante apocalípticamente optimista de la visión de de Maistre, en sus obras se apunta la conciencia de la des-cristianización progresiva de Occidente y la necesidad de una nueva cristianización para volver al equilibrio, impulsada por la mano terrible de la Providencia. Esta visión del fin de la Cristiandad, es más acusada en el pesimismo de Donoso. Cree que, aunque su deber y el de los buenos cristianos es luchar, la batalla está perdida.

«En un mot, s'il ne se fait pas une révolution morale en Europe; si l'esprit religieux n'est pas renforcé dans cette partie du mode, le bien social est dissous». ${ }^{46}$

«Una sola cosa puede evitar la catástrofe; una y nada más; eso no se evita con dar más libertad, más garantías, nuevas constituciones; eso se evita procurando todos, hasta donde nuestras fuerzas alcancen, provocar una reacción saludable, religiosa. Ahora bien, señores: ¿es posible esta reacción? Posible lo es; pero ¿es probable? Señores, aquí hablo con la más profunda tristeza, no lo creo probable. Yo he visto, señores, y conocido a muchos individuos que salieron de la fe y han vuelto a ella; por desgracia, señores, no he visto jamás a ningún pueblo que haya vuelto a la fe después de haberla perdido».47

\footnotetext{
44 Joseph de Maistre, Euvres..., vol V, p.241.

45 Juan Donoso CoRTÉs, Obras..., vol II, p. 305.

46 Joseph de MAistre, Oeuvres..., vol I, p. 26.

47 Juan Donoso CoRTÉs, Obras..., vol II, p. 201.
}

Hispania Sacra, LXIII

127, enero-junio 2011, 235-260, ISSN: 0018-215-X 


\section{EL FRACASO DE LA MODERNIDAD Y LA DICTADURA DE LA RAZÓN}

La aportación fundamental de de Maistre a la teoría política, no es la construcción de un sólido sistema teórico, sino su lúcida crítica del sistema democrático/revolucionario, la aguda puesta en evidencia de sus serias contradicciones internas y su capacidad para desmontar afirmaciones a primera vista incontestables. Ataca el problema fundamental de todo sistema político que pretenda fundamentarse autónomamente desde su interior: su inevitable necesidad de afirmaciones dogmáticas y apodícticas, que, aun resultando en sí mismas una «contradictio in terminis» con el discurso político que pretenden fundamentar, son indispensables para poder desarrollar el mismo.

Donoso recogerá esto y aporta matices aun más tenebrosos. Profundizando en la incapacidad epistemológica del hombre, arremete contra la voluntad racionalista de «autonomizar» la razón, porque lleva al desastre:

«El hombre prevaricador y caído no ha sido hecho para la verdad, ni la verdad para el hombre prevaricador y caído. Entre la verdad y la razón humana, después de la prevaricación del hombre, ha puesto Dios una repugnancia mortal y una repulsión invencible (...) Por el contrario, entre la razón humana y lo absurdo hay una afinidad secreta, un parentesco estrechísimo; el pecado los ha unido con el vínculo de un indisoluble matrimonio (...) Yo no sé si hay algo debajo del sol más vil y despreciable que el género humano fuera de las vías católicas».48

Se esfuerza en mostrar cómo las instituciones políticas no pueden auto-fundamentarse. Enlazando con el punto anterior, niega que el solo ejercicio de la razón sea capaz de cimentar el edificio político, que necesita siempre, para ser incontestable, del apoyo de algo que esté más allá de lo puramente humano.

\footnotetext{
«Cuando la voluntad se emancipa de Dios y la razón de la Iglesia, el error y el mal reinan sin contrapeso en el mundo».49
}

De aquí, dos consecuencias. En primer lugar, afirmado el principio de la necesidad de lo trascendente para fundamentar de forma sólida cualquier sistema político, queda claro que sin la aceptación acrítica de la ética proveniente de la Revelación es imposible cualquier forma política. Por eso la filosofía política resulta inevitablemente teología política. En segundo lugar, su teoría de lo inútil y pernicioso del diálogo/decisión de la mayoría, se entiende claramente, en este contexto, pues la razón, incapaz por sí misma, debe asentir ante las verdades reveladas. Entre el bien y el mal no existen espacios intermedios. En política, como en la vida, no los hay entre virtud y pecado.

\footnotetext{
48 Juan DonOso CoRTÉs, Obras..., vol II, pp. 380-381.

49 Ibidem, vol II, p. 325.
} 
«Ceux qui croient qu'en multipliant les voix délibérantes on diminue le doute connaissent peu l'homme, et n'ont jamais siégé au sein d'un corps délibérant».50

«Toutes les institutions imaginables reposent sur une idée religieuse, ou ne font que passer. Elles sont fortes et durables à mesure qu' elles sont divinisées, s'il est permis de s'exprimer ainsi». ${ }^{51}$

De la deliberación no puede salir la verdad pues esta ya ha sido definida a través de la Revelación. Por eso la sociedad que se mantiene fiel al principio religioso sobrevive, mientras se pierde la que relativiza la verdad y la decide no por sumisión a la Revelación sino por votación.

«El principio electivo es cosa de suyo tan corruptora, que todas las sociedades civiles, así antiguas como modernas, en que ha prevalecido, han muerto gangrenadas; el principio religioso es, por el contrario, un antipútrido tan excelente, que no hay corrupción que resista a su contacto, por eso no hay noticia de que haya muerto por corrupción ninguna sociedad verdaderamente católica». 52

De Maistre ve en la Revolución una herramienta brutal de la Providencia de acuerdo con su teoría de la reversibilidad del dolor y su tesis escatológica. El tiempo transcurrido entre los dos pensadores permite a Donoso ir más allá. En sus textos fundamentales denunciará que, tras las apariencias, los sistemas revolucionarios son un tipo más de totalitarismo, en extremo violento, pues han convertido a la razón revolucionaria en una especie de pseudo-religión. Amparándose en esta creencia dogmática, sus seguidores protagonizarán las mayores tropelías.

Como observa también de Maistre, Donoso advierte de otro de los problemas de la des-cristianización de la sociedad: la eliminación de los filtros «morales» en la acción política, por lo que a partir de entonces todo está «racionalmente» permitido.

«Français, c'est au bruit des chants infernaux, des blasphèmes de l'athéisme, des cris de mort et des longs gémissements de l'innocence égorgée; c'est à la lueur des incendies, sur les débris du trône et des autels, arrosés par le sang du meilleur des Rois et par celui d'une foule innombrable d'autres victimes; c'est au mépris des mœurs et de la foi publique, c'est au milieu de tous les forfaits, que vos séducteurs et vos tyrans ont fondé ce qu'ils appellent «votre liberté».53

«Un poder absoluto, para que lo sea, es menester que sea un poder expedito, y para que sea expedito es menester que no encuentre resistencias. Antes señores, había corporaciones unidas por el vínculo del amor, unidas por el vínculo de la religión; estas corporaciones oponían un dique a todo despotismo que quisiera levantarse en la nación». ${ }^{54}$

\footnotetext{
50 Joseph de MAISTRE, opus cit., vol II, p. 154.

51 Ibidem, vol I, p. 56.

52 Juan Donoso CORTÉs, opus cit., vol. II, p. 330.

53 Joseph de MAistre, Oeuvres..., vol I, p. 123.

54 Juan Donoso CoRTÉs, Obras..., vol II, p. 332.
} 
«iLa libertad acabó! No resucitará, señores, ni al tercer día ni al tercer año, ni al tercer siglo quizá. ¿Os asusta, señores, la tiranía que sufrimos? De poco os asustáis; veréis cosas mayores. (...) El mundo, señores, camina con pasos rapidísimos a la constitución de un despotismo, el más gigantesco y asolador de que hay memoria en los hombres». 55

De Maistre, fiel a la teoría de la soberanía descendente, reivindica el papel de la aristocracia como única clase rectora de la sociedad, designada por Dios.

«La philosophie moderne, qui aime tant parler de hasard, parle surtout du hasard de la naissance; c'est un de ses textes favoris: mais il n'y a pas plus de hasard sur ce point que sur d'autres: il y a des familles nobles comme il y des familles souveraines. L'homme peut-il faire un souverain? Tout au plus il peut servir d'instrument pour déposséder un souverain déjà prince. Du reste, il n'a jamais existé de famille souveraine dont on puisse assigner l'origine plébéienne: si ce phénomène paraissait, ce serait une époque du monde».56

Donoso, en una coyuntura diferente, acusa a los sistemas liberales revolucionarios de simplemente haber cambiado el dominio de la aristocracia por otra minoría, más triste y ramplona, la plutocrática, que tiende además a identificar con la burguesía. Probablemente la cuestión de las desamortizaciones está presente en su reflexión.

«El personaje más corrompido y más corruptor de esta sociedad es la clase media que nosotros representamos, señores; en esta clase hay voces de alabanza para todos los fuertes: de ahí salieron aquellas grandes voces que decían a la Milicia Nacional: «Eres benemérita»; y después a la Constitución de Cádiz: «Eres sacrosanta»; y luego al duque de la Victoria: «Eres heroico», y ahora al duque de Valencia: «Eres invicto».57

\section{AUTORIDAD Y «DECISIONISMO»}

«Tan pronto como Donoso Cortés advierte que la época de la monarquía ha terminado porque ya no hay reyes y ninguno de ellos tendría valor de serlo sino por la voluntad popular, lleva su decisionismo a una conclusión; es decir, pide una dictadura política. Ya en las citadas observaciones de de Maistre latía una reducción del Estado al factor decisión; consecuentemente, a una decisión, que no razona ni discute, ni se justifica, es decir, creada de la nada y absoluta. Mas esencialmente, esto es dictadura, no legitimidad dinástica. Donoso Cortés estaba convencido de que había llegado el instante de la lucha final; frente a lo radicalmente malo sólo cabe una dictadura, y la idea legitimista de sucesión dinástica se convierte en tal coyuntura en vacío legismo».58

\footnotetext{
55 Ibidem, vol II, p. 197.

56 Joseph de MaISTRE, Oeuvres..., vol I, pp. 149-150.

57 Juan Donoso CoRTÉs, Obras..., vol II, p. 329.

58 Carl SchMITT, Interpretación europea de..., p. 94.
} 
Este texto de Schmitt ha marcado el análisis de Donoso y su pretendido «decisionismo».59 Sin embargo conviene matizar su tesis. Sobre la autoridad, una vez más, bebe de las fuentes de de Maistre, tanto en la necesidad y bondad de la misma, como en su sentido «descendente», esto es, desde las alturas de la divinidad hacia la humanidad.

«L'infaillibilité dans l'ordre spirituel, et la souveraineté dans l'ordre temporel, sont deux mots parfaitement synonymes. L'un et l'autre expriment cette haute puissance qui les domine toutes, dont toutes les autres dérivent, qui gouverne et n'est pas gouvernée, qui juge et n'est pas jugée». ${ }^{60}$

«Señores, la verdadera causa del mal hondo y profundo que aqueja a la Europa está en que ha desaparecido la idea de la autoridad divina y de la autoridad humana. Ése es el mal que aqueja a la Europa, ése es el mal que aqueja a la sociedad, ese es el mal que aqueja al mundo; y por eso, señores, son los pueblos ingobernables». ${ }^{61}$

Existe en cualquier caso una gran diferencia entre ambos. De Maistre es claramente «decisionista», pues lo importante está en la necesidad de tomar decisiones, de ordenar y por tanto obedecer, la autoridad resulta incontestable. ${ }^{62}$

59 «Es soberano quien decide el estado de excepción» (Carl SchmitT, Teología política I. Cuatro capítulos sobre la teoría de la soberanía, en Héctor ORESTEEs (prólogo y selección de textos), Carl Schmitt, teólogo de la política..., p. 23) Probablemente esta emblemática frase de Schmitt con la que abre su Teología política resulta un buen resumen del concepto de decisionismo. Héctor Orestes en su prólogo a la obra citada, desmenuza el concepto en tres proposiciones fundamentales:

«1. La decisión es el principal acontecimiento político.

2. La soberanía descansa en el poder definitivo de la decisión.

3. El poder de decisión acerca de y durante el estado de emergencia es la manifestación definitiva de la soberanía». (Héctor OREstees (prólogo y selección de textos), Carl Schmitt, teólogo de la política..., p. 12).

Así, del mismo modo que el milagro divino no destruye el orden natural de las cosas, sino que lo ajusta y perfecciona, el soberano imponiendo el estado de excepción puede alterar la situación normativa imperante para acabar con el caos y garantizar la paz y con ella la propia posibilidad del estado normativo: «En términos políticos, la noción de estado de excepción supone el momento en que la legalidad, existente hasta ahora, sea cual sea, es ineficaz. (...) En los momentos de la ineficacia de la legalidad, el estado de excepción se abre a la fuente de ley y reclama la necesidad de una intervención trascendente que renueve el orden jurídico». (José Luis VillaCAÑAs, Poder y conflicto. Ensayos sobre Carl Schmitt, Madrid, Biblioteca Nueva, 2008, p. 117).

60 Joseph de Maistre, Oeuvres..., vol II, p. 2.

61 Juan Donoso CoRTÉs, Obras..., vol II, p. 306.

62 «Contra el espíritu de la revolución, primero de la revolución liberal, más adelante de la revolución socialista, la lucha de la Restauración se funda en la costumbre y la tradición. Para de Maistre la decisión del Estado se identifica con la soberanía. La soberanía del Estado, al igual que en la Iglesia, es sinónimo de infalibilidad. Todo gobierno es absoluto: «tout gouvernement est bon lorsqu'il est établi». Para él se trata de escoger entre la autoridad y la anarquía. No importa el contenido de la decisión, sino la prontitud con que se toma. Lo esencial es mandar, pues se parte de que todo gobierno, por el hecho de serlo y porque la autoridad viene de Dios, es necesariamente bueno, «puesto que está establecido». (Luis Villar Borda, Donoso Cortés y Carl Schmitt, Bogotá, Universidad Externado de Colombia 2006, p. 31).

Hispania Sacra, LXIII

127, enero-junio 2011, 235-260, ISSN: 0018-215-X 
Para entender su postura debe recordarse el lugar central del providencialismo en su pensamiento y su esperanza escatológica. En sus escritos aparece la convicción de que la divinidad mueve los hilos de la historia activamente, encaminándola, pese a lo oscuro de los tiempos, hacia un desenlace cercano y feliz. Es inútil cualquier resistencia por parte de los hombres, que deben aceptar lo que llega desde arriba, aun sin comprenderlo. Eso sucede con la Revolución Francesa. Pese a significar la encarnación del horror y del mal, es un instrumento de la voluntad de Dios para su plan último.

«Lorsque l'autorité commande, il n’y a que trois partis a prendre: l'obéissance, la représentation et la révolte, qui se nomme «hérésie» dans l'ordre spirituel, et «révolution» dans l'ordre temporel. Una assez belle expérience vient de nous apprendre que les plus grands maux résultant de l'obéissance n'égalent pas la millième partie de ceux qui résultent de la révolte». 63

Donoso, frente a este inmanentismo optimista mantiene su interpretación meta-histórica trascendente, cercana a San Agustín. No cree que el bien triunfe en la tierra. Según su visión «profética», el mundo camina a la catástrofe, de la mano del filosofismo y del abandono de la religión. Su realismo político, curtido en mil batallas parlamentarias, le hace ver que la monarquía no volverá al absolutismo. Esta es la perspectiva de su Discurso sobre la dictadura. Alejado del iluminismo escatológico de de Maistre, cree que un gobierno se legitima no por la forma en que se ha hecho con el poder, sino por su adhesión al bien, a la verdad revelada.

Aparece de fondo un nominalismo implícito: no existen el bien y el mal como entes autónomos de la razón, sino la aceptación o no de la voluntad de Dios. Llegados al momento de la lucha final, sólo hay dos posturas. Por una parte se presenta un gobierno que sigue los dictados del cristianismo, y que, de forma mecánica, adquiere una serie de virtudes que él llama democráticas, preocupación por toda la sociedad, la justicia, la caridad... Este gobierno sea cual sea su vía de acceso al poder, al obrar así, se legitima. O bien, se acepta otro modo de gobierno que se aleja del bien e inevitablemente cae en el mal, pues no hay zonas intermedias entre ambos. Ese gobierno es ilegítimo y antisocial. Cree Donoso inútil el contraste de opiniones. Desconfía de las clases burguesas discutidoras. El bien ha sido definido por la revelación cristiana. El único camino es seguirlo.

«Señores: ¿cuál es el principio del señor Cortina? El principio de su señoría, bien analizado su discurso, es el siguiente: en la política interior, la legalidad: todo por la legalidad, todo para la legalidad; la legalidad siempre, la legalidad en todas circunstancias, la

63 Joseph de Maistre, Oeuvres..., vol II, p. 89. 
legalidad en todas ocasiones; y yo, señores, que creo que las leyes se han hecho para las sociedades, y no las sociedades para las leyes, digo: la sociedad, todo para la sociedad, todo por la sociedad; la sociedad siempre, la sociedad en todas circunstancias, la sociedad en todas ocasiones.

Cuando la legalidad basta para salvar la sociedad, la legalidad; cuando no basta, la dictadura». ${ }^{64}$

«El catolicismo, la monarquía, la democracia, ved ahí completa la verdad española (...) Cuando yo hablo de Monarquía democrática, de gobierno democrático, no hablo de la Monarquía de las turbas. La Monarquía democrática es aquella en que prevalecen los intereses comunes sobre los intereses privilegiados, los intereses generales sobre los intereses aristocráticos». ${ }^{65}$

Más allá de la diferencia de matices, de Maistre está siempre muy presente en Donoso. En su concepción teológico-política, toma prestado uno de los planteamientos iniciales de las Considérations. ${ }^{66}$ Profundizando en él argumenta para explicar y defender la dictadura. De la misma forma que en el plano religioso encontramos el milagro como una forma legítima y positiva de romper de forma excepcional el curso natural de los acontecimientos, igualmente la dictadura sería la trasposición de este concepto a la política. Este paralelismo está de forma germinal en de Maistre:

«Le miracle est un effet produit par une cause divine ou surhumaine, qui suspend ou contredit une cause ordinaire. Que dans le cœur de l'hiver, un homme commande à un arbre, devant mille témoins, de se couvrir subitement de feuilles et de fruits et que l'arbre obéisse, tout le monde criera au miracle, et s'inclinera devant le thaumaturge. Mais la révolution française, et tout ce qui se passe en Europe dans ce moment, est tout aussi merveilleux dans son genre que la fructification instantanée d'un arbre au mois de janvier: cepedant les hommes, au lieu d'admirer, regardent ailleurs o déraisonnent».67

Años después, Juan Donoso legitima la dictadura y la fundamenta, «consuetudinariamente», usando el paralelismo con el milagro:

«Pues bien señores: si con respecto al mundo físico, Dios es el legislador, con respecto a las sociedades humanas lo son los legisladores, si bien de diferente manera, ¿gobierna Dios siempre con esas mismas leyes que Él a sí mismo se impuso con su eterna sabiduría y a las que nos sujetó a todos? No, señores; pues algunas veces, directa, clara y explícitamente manifiesta su voluntad soberana quebrantando esas leyes que Él mismo se impuso y torciendo

${ }^{64}$ Juan Donoso CoRTÉs, Obras..., vol II, p. 188.

65 Ibidem, vol II, p. 17.

${ }^{66}$ Este paralelismo es también destacado por Schramm, quien sin embargo, se muestra despectivo con la aportación de de Maistre, llegando a afirmar que el suyo es apenas un «vulgar símil»(Edmund Schramm, Donoso Cortés..., pp. 171-172) no apreciando que la postura de Donoso no es sino una profundización que parte de la idea inicial de Maistre.

${ }^{67}$ Joseph de MAISTRE, Oeuvres..., vol I, pp. 2-3.

Hispania Sacra, LXIII

127, enero-junio 2011, 235-260, ISSN: 0018-215-X 
el curso natural de las cosas. Y bien, señores: cuando obra así, ¿no podría decirse, si el lenguaje humano pudiera aplicarse a las cosas divinas, que obra dictatorialmente?» ${ }^{68}$

Es significativo y nada casual, pues muestra su conocimiento de ambos autores, que años después Carl Schmitt se apoye y use esta idea para su concepto de teología política. ${ }^{69}$

«En la jurisprudencia, el estado de excepción tiene un significado análogo al del milagro en teología. Sólo al tomar en cuenta esta posición análoga es posible reconocer la evolución experimentada por las ideas de la filosofía del Estado durante los últimos siglos. La idea del moderno Estado de derecho se impone con un deísmo, una teología y una metafísica que proscriben el milagro, rechazando la violación de las leyes naturales implícita en este concepto, misma que por su injerencia directa se establece como excepción, al igual que la intervención directa del soberano en el orden jurídico vigente». ${ }^{70}$

Hay entre Donoso y de Maistre diferencias de estilo. Aquel alcanza una profundidad política superior, pero la prosa de este ofrece al lector una mayor perspicacia y una facilidad para la paradoja que hacen su texto algo siempre fresco y atrayente.

«Nos idées sur le bien et le mal, sur l'innocent et le coupables, sont trop souvent altérées par nos préjuges. Nous déclarons coupables et infâmes deux hommes qui se battent avec un fer long de trois pouces; mais si le fer a trois pieds, le combat devient honorable». ${ }^{71}$

Donoso, aunque podemos afirmar con certeza que conocía el texto de de Maistre, utiliza la misma imagen, pero con sentido no sólo contrario, sino mucho más previsible y tópico, primando más el convencionalismo social que la profundidad del mensaje político:

«Se trata de escoger entre la dictadura que viene de abajo y la dictadura que viene de arriba: yo escojo la que viene de arriba, porque viene de regiones más limpias y serenas; se trata de escoger, por último, entre la dictadura del puñal y la dictadura del sable: yo escojo la dictadura del sable, porque es más noble». ${ }^{72}$

68 Juan Donoso CORTÉs, Obras..., vol II, p. 188.

${ }^{69}$ La utilización de esta idea sirve además de claro ejemplo de lo que queríamos decir cuando, en el primer apartado de este artículo, siguiendo a Carles Llinàs, mencionábamos la posible distinción entre teología política y política teológica, pues la analogía que Schmitt toma de de Maistre y Donoso resulta una clara subordinación de un concepto teológico a uno político.

${ }^{70}$ Carl Schmitt, Teología política I. Cuatro capítulos sobre la teoría de la soberanía... p. 43.

71 Joseph de Maistre, Oeuvres..., vol I, pp. 9-10.

72 Juan Donoso CoRTÉs, Obras, vol II, p. 204. 


\section{ULTRAMONTANISMO}

El liberalismo isabelino adopta desde sus inicios una actitud decididamente regalista. El Gobierno quiere controlar a la Iglesia Española y no acepta someter sus decisiones en esta materia a la aprobación de Roma. Probablemente las desamortizaciones resulten el epítome de esta actitud. Con todo, el movimiento regalista en España apenas tuvo seguidores, especialmente entre las filas eclesiásticas y sectores afines. No hubo aquí una división del clero como sucedió en Francia y otras naciones europeas.

La Iglesia Católica española se adhirió a las teorías que defendían la supremacía del Papa en la Iglesia, su infalibilidad y su independencia. Sus disposiciones estaban por encima de las de cualquier gobierno. Se explica así el éxito de las obras de de Maistre y especialmente $\mathrm{Du}$ Pape, auténtico y radical alegato en favor del poder soberano del Sumo Pontífice.

Donoso nunca fue regalista. Defendió siempre, en la línea del «profeta del pasado», la infalibilidad del Papa y su supremacía absoluta dentro del orden jerárquico de la Iglesia:

«Sin duda ninguna, el poder espiritual es lo principal en el Papa; el temporal es accesorio; pero ese accesorio es necesario. El mundo católico tiene el derecho de exigir que el oráculo infalible de sus dogmas sea libre e independiente; el mundo católico no puede tener una ciencia cierta, como se necesita de que es independiente y libre sino cuando es soberano, porque el soberano no depende de nadie». ${ }^{73}$

«Considerada desde el punto de vista de su organismo interior, la Iglesia se ha visto en la necesidad de resistir la grande venida de perniciosísimos errores, siendo digno de advertirse que entre ellos los más perniciosos son los que se dirigen contra lo que su unidad tiene de maravillosa y perfecta; es decir, contra el Pontificado, piedra fundamental del prodigioso edificio. En el número de estos errores está aquel en virtud del cual se niega al Vicario de Jesucristo en la tierra la sucesión única e indivisa del poder apostólico en lo que tuvo de universal, suponiendo que los obispos han sido sus coherederos. Este error, si pudiera prevalecer, introduciría la confusión y el desconcierto en la Iglesia del Señor, convirtiéndola, por la multiplicación del Pontificado, que es la autoridad esencial, la autoridad indivisible, la autoridad incomunicable, en una aristocracia turbulentísima. Dejándole el honor de una vana presidencia y quitándole la jurisdicción real y el gobierno efectivo, EL Sumo Pontífice, bajo el imperio del error deísta, queda relegado inútilmente en el Vaticano, como Dios, bajo el imperio del error deísta, queda relegado inútilmente en el cielo, y como el rey, bajo el imperio del error parlamentario, queda relegado inútilmente en su trono». .4

${ }^{73}$ Juan Donoso CoRTÉs, Obras..., vol II, p. 202.

${ }^{74}$ Ibidem vol II, pp. 756-757. 
Seguidor de de Maistre y creador de una auténtica «teología política», se le puede considerar defensor de ideales teocráticos..$^{75}$ Además de afirmar la infalibilidad del obispo de Roma y su superior autoridad, Donoso defendió la independencia de la Iglesia frente a los poderes políticos nacionales y la superioridad del poder espiritual sobre el terrenal, del que es guía y tutor. Esta postura se retrotrae doctrinalmente hasta Bonifacio VIII.

«Por lo dicho se ve que en el último análisis y en el último resultado de todos estos errores, en su variedad casi infinita, se resuelven en uno solo, el cual consiste en haber desconocido o falseado el orden jerárquico, inmutable de suyo, que Dios ha puesto en las cosas. Ese orden consiste en la superioridad jerárquica de la fe sobre la razón, de la gracia sobre el libre albedrío, de la Providencia divina sobre la libertad humana y de la Iglesia sobre el Estado; y para decirlo todo de una vez y en una sola frase, en la superioridad de Dios sobre el hombre.(...) La superioridad de la Iglesia sobre las sociedades civiles es una cosa conforme a la recta razón, la cual nos enseña que lo sobrenatural es sobre lo natural y lo divino sobre lo humano; y al revés, toda aspiración por parte del Estado a absorber la Iglesia, o a separarse de la Iglesia, o a prevalecer sobre la Iglesia, o a igualarse con la Iglesia, es una aspiración anárquica, preñada de catástrofes y provocadora de conflictos». ${ }^{76}$

\section{LA «TEORÍA DE LA GUERRA»}

Las ideas de Joseph de Maistre sobre la guerra son un corolario de su visión esencial y radicalmente providencialista de la historia. La guerra actúa como instrumento divino de expiación y de reversibilidad del dolor del inocente. Describe a los hombres como marionetas que, bajo los hilos del plan secreto de Dios, se entregan al frenesí de horror y sangre que supone la guerra. ${ }^{77}$ En sus textos, esencialmente la velada séptima y el tercer capítulo de las Considérations, hay imágenes vivas y cuadros apocalípticos con una prosa turbadora y bella a la vez.

\footnotetext{
${ }^{75}$ En realidad, el integrismo religioso del pacense se sitúa en una línea de pensamiento teocrático perfectamente desarrollada en el tiempo y que tiene su origen en la carta que el Papa Gelasio $(+496)$ envía al emperador de oriente Anastasio I donde esboza su famosa teoría de las dos espadas, propuesta donde se adivina ya la voluntad de supremacía de lo religioso sobre lo político (auctoritas versus potestas). Línea ideológica que podemos seguir después en la posición del monje Hildebrando (Gregorio VII) en su lucha contra el emperador alemán Enrique IV (recordemos la famosa escena de la humillación de Canosa) y que tiene su culminación el 18 de noviembre de 1302 con la publicación por parte de Bonifacio VIII de la bula Unam sanctam, auténtico epónimo de la ideología teocrática pontificia.

76 Juan DONOSO CORTÉs, Obras..., vol II, pp. 759-760.

${ }^{77} \mathrm{Su}$ teoría de la guerra puede interpretarse a su vez como una terrible y descarnada metáfora de la vida en el mundo, donde los hombres construyen la historia a ciegas, sin saber muy bien porqué ni hacia donde, (incapaces epistemológicamente y pecadores) guiados por el brazo omnisciente de la Providencia.
} 
Donoso es quizás menos original. En sus Cartas de París, prácticamente copia sin aportar mucho más, las ideas de de Maistre. Hay aquí sí, entre ambos, la distancia entre maestro y alumno. ${ }^{78}$

Bastan tres ejemplos.

La guerra como un hecho inevitable y connatural al hombre y las naciones:

«L'histoire prouve malheureusement que la guerre est l'état habituel du genre humain dans un certain sens; c'est-à-dire, que le sang humain doit couler sans interruption sur le globe, ici ou là; et que la paix, pour chaque nation, n'est qu'un répit». ${ }^{79}$

«Abrid las páginas de la Historia, extended los ojos por el mundo, preguntad a los siglos; los siglos, el mundo y la Historia, todos os hablarán de la guerra, su universalidad arguye su necesidad, y su necesidad le constituye en un hecho «humano»; es decir, en un hecho propio de la naturaleza del hombre».80

\section{La guerra como generadora de civilización:}

«Or les véritables fruits de la nature humaine, les arts, les sciences, les grandes entreprises, les hautes conceptions, les vertus mâles, tiennent surtout à l'état de guerre» ${ }^{81}$

«La segunda idea que nos acomete al proseguir este estudio es la de que la guerra acaba con las artes y las ciencias que florecen en la paz y, por consiguiente, con la civilización de las sociedades humanas. (...) Y sin embargo, si hay un hecho que proclame en alta voz el mundo y que consigne claramente la Historia, es el hecho de la acción civilizadora de la guerra; su acción es civilizadora hasta tal punto, que, si la suprime el entendimiento, todos los progresos sociales quedan suprimidos, todas las civilizaciones quedan aniquiladas». ${ }^{82}$

La imagen sorprendentemente idealizada y honorable de la matanza que es la guerra.

«Voici donc le problème que je vous propose: Expliquez pourquoi ce qu'il y a de plus honorable dans le monde, au jugement de tout le genre humain, sans exception, est le droit de verser innocemment le sang innocent? Regardez-y de près, et vous verrez qu'il y a quelque chose de mystérieux et d'inexplicable dans le prix extraordinaire que les hommes ont toujours attaché à la gloire militaire».83

«El guerrero camina por el mundo rodeada la frente de una aureola de gloria; a su paso le aclaman los hombres; sus hijos se envanecen; sus hermanos le honran; (...) ¿Es

78 «Divina o no, la guerra, tal como aparece en las Veladas, ejerce sobre nosotros cierta fascinación. No sucede lo mismo cuando preocupa a espíritus de segundo orden como Donoso Cortés, discípulo de de Maistre». Emile CIORAn, Ensayo sobre el pensamiento reaccionario, Barcelona, Montesinos 1985, p. 22.

79 Joseph de MAISTRE, Oeuvres..., vol I, p. 28.

80 Juan DonOso CORTÉs, Obras..., vol I, p. 771.

${ }^{81}$ Joseph de MAistre, Oeuvres..., vol I, p. 36.

82 Juan DONOSO CORTÉs, Obras..., vol I, p. 773.

${ }^{83}$ Joseph de Maistre, Oeuvres..., vol V, p. 10.

Hispania Sacra, LXIII

127, enero-junio 2011, 235-260, ISSN: 0018-215-X 
injusta la Humanidad, por ventura, cuando teje coronas para los guerreros, al mismo tiempo que levanta cadalsos para los matadores? (...) Y si la Humanidad obrando así tiene razón, ¿qué poderosa, qué oculta virtud se esconde en ese fenómeno maravilloso de la guerra que purifica a los matadores, que santifica la muerte?

En ese fenómeno hay un misterio, un misterio profundo, un enigma terrible, un fenómeno que existe y que no lleva en sí mismo la razón de su existencia». ${ }^{84}$

Ambos establecen un paralelismo o asimilación entre el estado militar y el religioso, pues, de algún modo, uno y otro tienen un mismo sentido de autoridad y, por tanto, de obediencia.

«Les écrivains de qui nous tenons ces anecdotes vivaient cependant dans un siècle passablement guerrier, ce me semble: mais c'est que rien ne s'accorde dans le monde comme l'esprit religieux et l'esprit militaire». .5

«Por eso, porque la Iglesia y la milicia son las únicas que conservan íntegras las nociones de la inviolabilidad de la autoridad, de la santidad, de la obediencia y de la divinidad de la caridad; por eso son hoy los dos representantes de la civilización europea». ${ }^{86}$

\section{CONCLUSIONES}

Juan Donoso Cortés es, junto a Jaime Balmes, el pensador político español más importante del siglo XIX y uno de los nombres fundamentales de la filosofía política española de todos los tiempos. Quien mayor influencia ejerce en su ideología fue Joseph de Maistre. Conviene añadir que Donoso elabora una construcción intelectual personal y propia. Su aportación a la reflexión política va más allá de la pura relación maestro-alumno,que algunos críticos reduccionistas de su obra, como Barbey d'Aurevilly o Cioran pretenden adjudicarle.

Donoso comparte con de Maistre y quizás de él lo recibió, un pesimismo antropológico, cuya fuente ideológica inicial remonta a san Agustín en su polémica con Pelagio. Sostiene su tesis de la incapacidad humana para conocer la verdad y hacer el bien de forma puramente racional, sin la ayuda de la gracia. La voluntad del hombre de autonomizar la razón respecto a la fe lleva inevitablemente al pecado.

Donoso traspasa a la sociedad esta concepción del hombre. Su filosofía de la historia deviene teología de la historia. En ella la Providencia es la clave, pues es la que rige a la sociedad y sus individuos, a toda la historia.

\footnotetext{
${ }^{84}$ Juan Donoso CoRTÉs, Obras..., vol II, p. 314.

${ }^{85}$ Joseph de MaISTRE, Euvres..., vol V, pp. 16-17.

86 Juan Donoso CoRTés, Obras..., vol II, p. 314.
} 
Hay entre Donoso y de Maistre una divergencia de fondo. Aquel se sitúa en una línea de filosofía de la historia, próxima a San Agustín, una «meta-historia», que ha conformado la línea ortodoxa de la tradición cristiana. La victoria del Reino de Dios se aplaza para la otra vida. De Maistre, en una línea más inmanente, «milenarista», la espera en la tierra, enlazando así con la literatura apocalíptica judía.

Desde estas dos convicciones, el pesimismo antropológico y la no autonomía de la razón, Donoso afirma que las instituciones políticas no pueden autofundamentarse, fuera de la fe en los principios revelados. La reflexión política debe nacer en y desde la teología.

Sobre la autoridad y el «decisionismo», Donoso, aun influido por de Maistre, se separa de él. Para de Maistre la autoridad es incontestable como expresión de la voluntad de la Providencia. De ahí la necesidad de tomar decisiones y sobre todo de obedecer. Donoso, en cambio, legitima a un gobierno por su adhesión al bien que no es sino la doctrina revelada. Si su acción no se aparta de ella, un Gobierno es legítimo sea cual sea la forma en que ha alcanzado el poder.

En las relaciones Iglesia-Estado, Donoso, fiel seguidor de las tesis del autor de $D u$ Pape, se muestra en todos sus escritos claramente ultramontano. 